\title{
Analyzing the Effects of Iranian EFL Textbooks on Developing Learners' Life Skills
}

\author{
Mahboobeh Khosravani ${ }^{1}$, Mahmood Khosravani ${ }^{2}$ \& Abbas Khorashadyzadeh $^{3}$ \\ ${ }^{1}$ Department of English Language, Chabahar Maritime University, Chabahar, Iran \\ ${ }^{2}$ Department of English Language, Ministry of Education, South Khorasan Province, Birjand, Iran \\ ${ }^{3}$ Department of English Language, Farhangian University, Birjand, Iran \\ Correspondence: Mahmood Khosravani, Department of English Language, Ministry of Education, South \\ Khorasan Province, Birjand, Iran. Tel: 989-156-662-951. E-mail: mdkhosravani@yahoo.com
}

Received: January 20, 2014 Accepted: May 12, 2014 Online Published: May 14, 2014

doi:10.5539/elt.v7n6p54 URL: http://dx.doi.org/10.5539/elt.v7n6p54

\begin{abstract}
Education is not an end, but a means to an end. The ultimate goal of education is to prepare students for their future life. Regarding this fact, English language classes and textbooks can be used as tools for improving learners' life skills. Meanwhile, informative textbooks with rich socio-cultural constructs that foster learners' life skills are needed. To assess the range of the Iranian EFL textbooks richness in these aspects, a life skills questionnaire was distributed among ELT teachers $(\mathrm{N}=73)$ and EFL learners $(\mathrm{N}=1112)$ almost all over Iran. The results originated from data analysis showed that Iranian EFL textbooks don't improve the EFL learners' essential life skills considerably especially leadership life skills, critical thinking life skills, and decision making/problem solving life skills. The findings of this research and the designed life skills questionnaire can be used by educational policy makers, syllabus designers, materials developers, researchers, teachers, etc. to examine and analyze the socio-cultural constructs of Iranian EFL textbooks for considering in the processes of publishing new EFL textbooks for the Islamic-Iranian society of Iran.
\end{abstract}

Keywords: life skills questionnaire, socio-cultural constructs, efl (English as a foreign language) textbooks, life skills

\section{Introduction}

\subsection{Background and Purpose}

"Education is not an end; But a means to an end. The goal of education is to prepare students for life." (Book three for Iranian high schools). Do we really apply these nice concepts to our EFL textbooks? Do our English language textbooks really prepare students for life? Do we really use English language as a means to teach our learners necessary life skills? Do we try to improve something else except for students' proficiency in our English language textbooks and classes? These were samples of questions that made the researchers enthusiastic to work on this topic. They try to concentrate on socio-cultural constructs of Iranian EFL textbooks and the possibility of developing learners' life skills. They want to see whether existed Iranian EFL textbooks play a considerable role on preparing students for their life and act as a means to the greater goal of developing life skills and to what extent.

According to Garinger (2001), "textbooks play an axial role in language classrooms in all types of educational institutions, public schools, colleges, and language schools - all over the world. In some contexts, teachers are free to choose their own textbooks. The vast majority of teachers, however, have textbooks suggested, prescribed, or assigned to them." (p. 34). This opinion is related to this study in clarifying the pivotal role of the textbooks in language classes.

In addition, Riazi (2003) believes that: "textbooks play a very pivotal role in the realm of language teaching and learning and are considered the next important element in the second/foreign language classroom after the teacher." (p. 21). Sheldon (1988) says that: "the textbook is a tool in the hands of the teacher, and the teacher must know not only how to use it, but also how useful it can be. The wealth of published materials for English language teaching (ELT) available in the market makes selecting the appropriate course book a challenging task. Moreover, the selection of a particular core textbook signals an executive educational decision in which there is 
considerable professional, financial, and even political investment" (p. 11). Based on these statements, the researchers are seeking for the cultural role of Iranian EFL textbooks in improving learners' life skills.

\subsection{Review of Related Literature}

Different areas of studies related to English Language Teaching (ELT) can be discussed in this part. Studies on textbooks evaluation, culture in ELT, life skills, etc. are presented and compared in the following parts in order to form the theoretical framework and background of this study.

\subsubsection{EFL Textbooks and Evaluating Them}

Azizifar, Koosha, and Lotfi (2009) introduce textbooks as necessary resources for instructors to help learners in the learning process of every subject, including English, which plays a fundamental role in school instruction. They add, in Iran, that most of the input and language practice obtained by students is via textbooks. "For the EFL learners, the textbook becomes the major source of contact they have with the language, apart from the input provided by the teacher" (p. 67).

McGrath (2002) believes that: "textbook evaluation is of an important criterion for the development and administration of language learning programs" (p. 11). Sheldon (1988) claims that textbooks provide the visible heart of any ELT program for both students and teachers. Therefore, this study can play an important role in determining the amount of Iranian EFL textbooks role in this area.

\subsubsection{Research on Textbooks Evaluation in Iran}

In Iran, different research projects have been implemented to evaluate textbooks, among which Amerian (1987), Kheibari (1999), Shahedi (2001), Yarmohammadi (2002), Ansary and Babaii (2002), and Amalsaleh (2004) are clear examples.

First, Amerian (1987) handled a comparative study of the first two Iranian EFL textbooks of Right Path to English and Books One and Two of the Graded English series based on Tucker's model. The findings of the reserach demonstrated that there are no significant differences between the two series. He said that this is because it can be claimed that both series represent the structural syllabus and design.

Then, Kheibari (1999) modified Tucker's model and applied it to the five volumes of "Teaching Persian to Speakers of Other Languages" (TPSOL) textbooks. She believed that the philosophy behind the changes is because of the recent improvements in language teaching. The results of that research showed that the books follow the Grammar Translation Method which pays the least attention to language skills such as speaking, role-playing, or different kinds of tasks.

After Kheibari, Shahedi (2001) analyzed one of the texts in TPSOL and mentioned that in these series, not enough attention has been attached to language four skills. Moreover, the form and amount of the presentation of pronunciation and vocabulary have no cooperation with EFL learners' proficiency levels.

Next, Yarmohammadi (2002) analyzed the senior high school textbooks according to a revised version of Tucker's model. He found that these textbooks contain a lot of shortcomings: "1. they are not authentic; 2. English and Persian names are used interchangeably; and 3. oral skills are ignored" (p. 78).

In that year, Ansary and Babaii (2002) considered a group of 10 EFL/ESL textbook reviews plus 10 EFL/ESL textbook evaluation checklists. Then, they outlined what they realized to be the core characteristics of standard EFL/ESL textbooks. The main themes include approach, content presentation, administration concerns, and physical make-up. Each group of main characteristics of EFL/ESL textbooks includes a number of subcategories. They concluded that not all of these features would be present in each and every textbook.

Finally, Amalsaleh (2004) worked on the representation of social factors in three types of textbooks, consisting of junior and senior high school textbooks, according to Van Leeuwen's model (1996). According to his findings, the textbooks revealed a significant representation of social factors that intended to suppose female as performers in relation to a home context and having limited job chances in society. In particular, junior and senior high school textbooks intended to form original views of class relations and sex in which a middle-class urban male was considered to be the norm.

\subsubsection{Presentation of Culture in ELT Textbooks}

Before going to presentation of culture in Iranian EFL textbooks that is presented in this project, some scholars' viewpoints on this issue will be discussed here. Chastain (1988) makes a relationship between "culture" and teaching of a second language by dividing it into two groups: small c culture and large $\mathrm{C}$ culture. Small c culture concerns the way people live, while large $\mathrm{C}$ culture has to do with the economic, social, and political history and 
the great politicians, heroes, writers, and artists of a country.

Alptekin and Alptekin (1984) believed that there should be a balance between the target culture and students' native culture. Also, Guest (2002) argued that culture should be taught indirectly while emphasizing pragmatic and linguistic universals. Based on Alptekin (1993), "teaching culture in EFL textbooks should move from familiar to unfamiliar and in this case unfamiliar could even be the international culture and not necessarily American or British culture" (p. 31).

In addition, McKay (2003) believes that "in the light of English as an international language, the cultural content of materials should not be limited to native English-speaking countries and should include local cultural content" (p. 311).

\subsubsection{Iranian Culture and ELT}

As the researchers are investigating the socio-cultural constructs of the Iranian EFL textbooks, culture is one of the issues that are directly related to the topic of this research. Culture has been defined in a number of ways. Linton (1945) defines culture as "a configuration of learned behaviors whose component elements are shared and transmitted by the members of a particular society" (p. 32). Also, Thompson (1990) introduces culture as "the pattern of meanings embodied in symbolic forms, including actions, utterances and meaningful objects of various kinds, by which individuals communicate with one another and share their experiences, conceptions and beliefs" (p. 132).

Considering Iranian society, as Talebinejhad and Aliakbari (2001) mentioned, "English seems to have found its way smoothly right to the heart of Iranian society, proving itself to be a necessity, rather than a mere school subject. Just as with the outer world, English is the dominant language of foreign trade, international seminars, for air traffic in international airports, and in sea navigation" (p. 3).

Aliakbari (2002) believes that: "As the preliminary words on the relationship between culture and ELT it can be said that Iran's relation with the world is mainly through English. Though native-like pronunciation, which is not contradictory to EIL assumptions, is aimed at in classrooms, native English speakers do not make up the sole possible interactions for Iranian English learners. In fact, English is often used for non-native interactions. English dailies, weeklies, journals and other English periodicals directed by Iranian nationals are issued and available throughout the country. The government's policy for increasing the export of non-oil products made companies and exporters take advantage of this medium to introduce their goods and products to the world market. The Iranian national TV has started broadcasting authentic foreign programs, especially English ones. The Internet, the use of which requires a substantial English proficiency level and through which people enjoy world relationships, has gained national recognition. Iran's cooperation with the UN, Islamic Conference Organization, ECO, OPEC and other regional and world organizations makes English a practical necessity for the involved nationals. International book fairs and trade exhibitions held annually in the capital demonstrate the country's readiness and its dependable capacity to maintain its world relationships in English" (p. 2).

There is an obvious absence of research that analyzes the quality and the types of materials utilized in teaching culture in Iranian textbooks more specifically at advanced level in which the students are to be proficient enough. In relation to Iranian context, Aliakbari (2002) carried out the same study on high school textbooks. He found that Iranian EFL textbooks currently in use in Iranian high schools are adequate in their representation of the target culture or other cultures.

Having all these definitions in mind, the researchers believe that culture should have a practical outcome in learners' behaviors. In other words, they define culture operationally. For example, if we say respecting older generations is a cultural value that learners should acquire, what are the practical teaching points in this regard? And what are practical outcomes in learners' behaviors? Therefore, the cultural values of each society should be defined operationally and become added to their educational system, and language textbooks.

\subsubsection{Life Skills and Their Classifications}

Anderson (2005) believed that life skills have a positive impact on the school behaviors. He added that life skills and Lifelong guidelines play a substantial role in producing a community of responsible citizens for life. Sawi and Smith (1997), Bender (2002), Fox et al. (2003), Boleman et al. (2004), and Maass et al. (2006) introduced instruments that were made up of a set of indicators, measuring life skills in content. El Sawi and Smith (1997) clarified that: "life skills, such as leadership, teamwork, decision making, problem solving, reasoning, communication and personal qualities such as responsibility, self-esteem, and integrity can be found in almost any description of a content and an extension youth program" (p. 12). Bender (2002) sketched a series of skills that contains the following: "decision making, problem solving, creative thinking, critical thinking, effective 
communication, interpersonal relating, self-awareness, ability to empathize, coping with emotions and coping with stress" (p. 41).

Fox et al. (2003) devided 32 life skills into four main categories: leadership skills, personal/social skills, technical skills, and communication skills. Boleman et al. (2004) considered specific life skills in their research as follows: develop and maintain records, decision-making, ability to relate to others, accept responsibility, self-motivation, build positive self-esteem, develop organizational skills, develop oral communication skills, ability to solve problems, set goals, work in teams, and develop self-discipline. Maass et al. (2006) categorized life skills into goal setting, critical thinking, communication, conflict resolution, problem solving, cooperation, decision-making, and community service.

It should be mentioned that in this study, the researchers have used a combination and mixture of the above mentioned classifications of life skills.

\subsection{Significance of the Study}

If we say that education is a means to the end of preparing learners for life, we should make our EFL textbooks full of beneficial and useful social and cultural constructs that explicitly and implicitly teach learners necessary life skills. Besides, Iran is a Muslim country that people need religious life skills in addition to pure social and cultural life skills. In other words, learners in Iran are living in a religious culture which requires special life skills.

As the examples of religious life skills, we can name faith and reliance in God, Practical belief to religious instructions (e.g. praying, fasting, veil), Islamic morality and behavior (e.g. being honest, depositary, self-controlled and avoiding backbiting), Praying in mosques, etc.

The findings of this study would be beneficial for educational policy makers, material developers, syllabus designers, teacher educators, researchers, teachers, etc. by showing them the inconveniences of Iranian EFL textbooks from the socio-cultural point of view.

Policy makers, material developers, and syllabus designers can add and present the social lives which are lost in the textbooks through different means and formats. Teacher educators can ask the teachers to cover the needed life skills in their teaching processes and class environments in the case of incomplete textbooks at those areas. Also, researchers can do more studies on this topic and help above-mentioned groups to know the importance of their responsibility in improving the learners' life skills and gain their necessary information through their research.

\subsection{Research Questions}

To address the above purposes of the study, the following questions were composed:

Q1. Is there any significant relationship between Iranian EFL textbooks socio-cultural constructs and learners' life skills?

Q2. Is there any significant relationship between Iranian EFL textbooks socio-cultural constructs and learners' social behaviors and their ability of establishing useful interactions with people as life skills?

\subsection{Research Hypotheses}

The researcher proposes the following null hypotheses to avoid subjectivity:

H0 1. There is no significant relationship between Iranian EFL textbooks socio-cultural constructs and learners' life skills.

H0 2. There is no significant relationship between Iranian EFL textbooks socio-cultural constructs and learners' social behaviors and their ability of establishing useful interactions with people as life skills.

\section{6 (De)Limitations}

The selected textbooks are just analyzed socio-culturally, and other constructs of those textbooks are neglected. In addition, the participants' sex is not considered in this study. Besides, the socio-cultural constructs of the textbooks are not separated sexually.

\section{Methodology}

\subsection{Participants}

1185 participants in two groups were selected randomly as the participants of this research. These groups were EFL teachers $(\mathrm{N}=73)$, and students $(\mathrm{N}=1112)$. The specifications of the participants are shown in the following parts. 


\subsubsection{Teachers}

73 Iranian EFL teachers with following specifications participated in this study and answered the questionnaire.

Table 1. Teachers' specifications

\begin{tabular}{|c|c|c|c|}
\hline & & Number & Percent \\
\hline \multirow{2}{*}{ Gender } & Male & 46 & $61 \%$ \\
\hline & Female & 27 & $39 \%$ \\
\hline \multirow{4}{*}{ Age } & $20-30$ & 39 & $53 \%$ \\
\hline & $30-40$ & 23 & $32 \%$ \\
\hline & $40-50$ & 9 & $12 \%$ \\
\hline & Over 50 & 2 & $3 \%$ \\
\hline \multirow{4}{*}{ Degree } & $\mathrm{AD}$ & 4 & $5 \%$ \\
\hline & BA & 38 & $52 \%$ \\
\hline & MA & 26 & $36 \%$ \\
\hline & $\mathrm{PhD}$ & 5 & $7 \%$ \\
\hline \multirow{2}{*}{$\begin{array}{l}\text { School } \\
\text { Section }\end{array}$} & Junior high school (secondary school) & 44 & $60 \%$ \\
\hline & Senior high school (high school) & 29 & $40 \%$ \\
\hline Provinces & $\begin{array}{l}\text { Lorestan, west Azarbayejan, Razavi Khorasan, Hormozgan, South Khorasan, } \\
\text { Golestan, Mazandaran, Yazd, Tehran, Khusestan, Qom, Zanjan, Sistan \& } \\
\text { Baloochestan, Ardebil, Kermanshah, North Khorasan }\end{array}$ & $\begin{array}{l}16 \text { out of } \\
31\end{array}$ & $52 \%$ \\
\hline
\end{tabular}

This table shows that 61 percent of participated teachers were male and 39 percent of them were female. Also it is clear in this table that about 85 percent of the teachers have ages between 20 and 40 and 15 percent of them are more than 40 years old. This table shows details about the teachers' university degree. Students of each degree level were considered as that specific level. For example, MA students are considered as MA holders in this table. As presented here, about $90 \%$ of teachers hold BA and MA degrees in TEFL and Linguistics. As it can be seen here, EFL teachers of ministry of education from different school sections participated in this step. 60 percent of them were junior high school teachers and 40 percent of them were senior high school teachers. This table also determines that EFL teachers from more than 50 percent of Iran provinces completed the questionnaire.

\subsubsection{Students}

1112 Iranian EFL learners participated in this study and answered the questionnaire.

Table 2. Students' specifications

\begin{tabular}{llcc}
\hline & & Number & Percent \\
\hline \multirow{2}{*}{ Gender } & Male & 708 & $64 \%$ \\
& Female & 404 & $36 \%$ \\
\hline \multirow{2}{*}{ School } & Junior high school (secondary school) & 689 & $62 \%$ \\
Section & Senior high school (high school) & 423 & $38 \%$ \\
\hline \multirow{2}{*}{ Provinces } & Razavi Khorasan, Hormozgan, South Khorasan, Golestan, Mazandaran, & 10 out of & \multirow{2}{*}{$32 \%$} \\
& Yazd, Tehran, Qom, Sistan \& Baloochestan, North Khorasan & 31 & \\
\hline
\end{tabular}

According to this table, about 64 percent of the students were male and 36 percent of them were female. Also, junior high school students were 62 percent and senior high school were 38 percent of the student participants. Students participated in this research come from 10 provinces out of 31 provinces in Iran. In other words, participated provinces are about 32 percent of Iran provinces. 


\subsection{Instrumentations}

\subsubsection{Life Skills Questionnaire}

A modified questionnaire containing one general question and 58 items in 5 groups was used in this project. The questionnaire of this research was designed based on the life skills classifications suggested by Maass (2006), Boleman (2004), Loeser (2004), Fox (2003), Bender (2002), etc. and content analysis cards used by Yousif Omar Hamdona (2007) in his MA thesis which was taken from Ferch (2005).

For validating the questionnaire, two university lecturers of TEFL were asked to check it from different points of views. Also for checking the reliability of the questionnaire, it was piloted among 23 male and female EFL teachers from different school sections and cities. More specifically, 13 teachers were male and 10 of them were female. Half of them were junior high schools ELT teachers and half of them senior high school ELT teachers. There were from 9 provinces of Iran. The result of Cronbach's Alpha for the piloting process was 0.77.

\subsection{Procedure}

This research had some separate steps that formed the whole project. These steps were modifying the questionnaire, distributing and collecting the questionnaires, and analyzing data. They are also explained in detail in the following parts.

\subsubsection{Modifying the Questionnaire}

After analyzing and comparing some various standard models and scholars' viewpoints on life skills, the questionnaire was modified and reorganized. It passed the validation and reliability processes successfully. (More explanations in part 2.2.1)

\subsubsection{Distributing and Collecting the Questionnaires}

Participated teachers were found through the researcher's friends and colleagues. Also, some of them were found through conferences and education offices of different provinces and cities. The questionnaires (teachers' and students' questionnaires) were sent to them via email. The teachers of other cities and provinces (except for the researcher's own city) were asked to print them and give them to their colleagues and students. After that, they sent the completed questionnaires through snail mail to the researcher. These processes had lasted about 3 months.

\subsubsection{Analyzing Data}

All collected questionnaires were carefully classified and their results were analyzed through SPSS software with consultation of statistics experts. The results of data analysis will be presented in the next part.

\subsection{Study Design}

This correlational study is both qualitative and quantitative. It is correlational because it wants to find the correlation between the life skills latent in the Iranian EFL textbooks and needed life skills for Iranian EFL learners. It is qualitative because the results of a questionnaire with Likert Scale format are not purely quantitative and can be considered as qualitative results too. That is because of the ambiguous distance between different choices mentioned in the Likert Scale format. It is quantitative because 1185 students and teachers answered the questionnaire of the research and the results were calculated with one statistics software. The researcher conducted this method due to its relevance and suitability for investigating life skills latent in Iranian EFL Textbooks.

\section{Results and Discussion}

\subsection{Results}

As the questionnaire of this research has 5 general parts, the results of each part are presented separately. After that, the relations between categories are analyzed.

\subsubsection{Communication/Linguistic Life Skills}

This part of the questionnaire consists of 14 items. They bring up the operational options of communication/linguistic life skills. First, a table on the percent of the answers for each item of this part is presented. Then, the internal consistency of this category is discussed. 
Table 3. The percent of the answers for each communication/linguistic life skill

\begin{tabular}{|c|c|c|c|c|c|}
\hline $\begin{array}{l}\text { Q: To what extent do your EFL textbook improve the following life } \\
\text { skills in learners? }\end{array}$ & $\begin{array}{l}\text { Very } \\
\text { high }\end{array}$ & High & Middle & Low & Nothing \\
\hline $\begin{array}{l}\text { Effective verbal and non-verbal communication with others that help } \\
\text { the students to establish relationships }\end{array}$ & 3 & 7 & 34 & 29 & 27 \\
\hline Expressing of feelings, ideas and opinions clearly & 1 & 17 & 31 & 27 & 24 \\
\hline Giving and receiving feedback & 3 & 14 & 33 & 26 & 24 \\
\hline Understanding other people's viewpoints & 2 & 14 & 24 & 38 & 22 \\
\hline Organizing thoughts to reflect logical thinking and speaking & 2 & 7 & 26 & 33 & 32 \\
\hline Influencing \& persuading others & 3 & 15 & 24 & 31 & 27 \\
\hline Expressing respect for others' contributions & 3 & 11 & 22 & 28 & 36 \\
\hline Learning how to criticize and reply/react criticisms & 2 & 11 & 20 & 30 & 37 \\
\hline $\begin{array}{l}\text { Respecting and tolerating opposite and various comments (Being } \\
\text { patient in relation with others) }\end{array}$ & 4 & 13 & 20 & 34 & 29 \\
\hline $\begin{array}{l}\text { Active listening (real situations like in classes, airports, shops, } \\
\text { watching films, listening to music, etc.) }\end{array}$ & 6 & 9 & 20 & 28 & 37 \\
\hline $\begin{array}{l}\text { Fluency and accuracy in speaking (real situations like in airports, } \\
\text { shops, etc.) }\end{array}$ & 3 & 11 & 28 & 28 & 29 \\
\hline $\begin{array}{l}\text { Correct reading and study skills (even newspapers, stories, novels, } \\
\text { etc.) }\end{array}$ & 2 & 12 & 39 & 27 & 20 \\
\hline $\begin{array}{l}\text { Using body language and gestures for conveying meaning and } \\
\text { understanding }\end{array}$ & 7 & 13 & 19 & 37 & 24 \\
\hline $\begin{array}{l}\text { Observance of lexical and grammatical/structural rules in written } \\
\text { utterances }\end{array}$ & 9 & 25 & 26 & 23 & 17 \\
\hline
\end{tabular}

According to these answers, the respondents believed that the Iranian EFL textbooks contains and improve the learners' mastery on "lexical and grammatical/structural rules in written utterances" (Very High+High=34\%) more considerably than the other items. On the other hand, they believed that the authors of these textbooks paid least attention to the life skills "Organizing thoughts to reflect logical thinking and speaking" (Nothing+Low $=65 \%)$, "Learning how to criticize and reply/react criticisms" $(\mathrm{N}+\mathrm{L}=67 \%)$, and "Active listening" $(\mathrm{N}+\mathrm{L}=65 \%)$ among the mentioned communications/Linguistic life skills. Also, except for the "Correct reading and study skills" and "Observance of lexical and grammatical/structural rules in written utterances" that their "low" and "nothing" choices are lower than 50 percent, the percent of "low" and "nothing" choices in the other items are more than 50. It shows that they need more attention in the process of preparing Iranian EFL textbooks.

\subsubsection{Personal/Social Life Skills}

This part of the questionnaire includes 11 items. They bring up the operational choices for personal/social life skills. First, a table on the percent of the answers for each item of this part is presented. Then, a brief discussion on the revealed information in the table and the internal consistency of this category are proposed.

Table 4. The percent of the answers for each personal/social life skill

\begin{tabular}{|c|c|c|c|c|c|}
\hline $\begin{array}{l}\text { Q: To what extent do your EFL textbook improve the following life } \\
\text { skills in learners? }\end{array}$ & $\begin{array}{l}\text { Very } \\
\text { high }\end{array}$ & High & Middle & Low & Nothing \\
\hline Developing of personal identity & 6 & 13 & 26 & 28 & 27 \\
\hline Respecting the social and cultural laws and values of the society & 12 & 15 & 22 & 30 & 21 \\
\hline Respecting others' values & 9 & 12 & 24 & 33 & 22 \\
\hline Acquiring of social responsibilities & 5 & 13 & 30 & 28 & 24 \\
\hline Truthfulness in action and speech & 13 & 14 & 26 & 27 & 20 \\
\hline $\begin{array}{l}\text { Respecting older generations (including parents, adults, and } \\
\text { teachers) }\end{array}$ & 7 & 9 & 22 & 33 & 29 \\
\hline
\end{tabular}




\begin{tabular}{|c|c|c|c|c|c|}
\hline Respecting other religions & 6 & 13 & 13 & 25 & 43 \\
\hline Discipline in life activities & 5 & 15 & 34 & 33 & 13 \\
\hline $\begin{array}{l}\text { Respecting and observance of people's right (e.g. in public places, } \\
\text { traffic rules, sin against mankind, etc.) }\end{array}$ & 5 & 13 & 30 & 33 & 19 \\
\hline Team and group work & 4 & 12 & 33 & 27 & 24 \\
\hline $\begin{array}{l}\text { Practical belief to religious values and instructions (e.g. praying, } \\
\text { fasting, veil, honesty, depositary, avoiding backbiting, finding good } \\
\text { friends, etc.) }\end{array}$ & 8 & 13 & 32 & 31 & 16 \\
\hline
\end{tabular}

Based on the respondents' answers, the Iranian EFL textbooks includes and develop the life skills "Respecting the social and cultural laws and values of the society" $(\mathrm{VH}+\mathrm{H}=27 \%)$ and "Truthfulness in action and speech" $(\mathrm{VH}+\mathrm{H}=27 \%)$ in the learners more considerably than the other items. On the other hand, they believed that these textbooks don't improve the life skills "Respecting older generations" $(\mathrm{N}+\mathrm{L}=62 \%)$ and "Respecting other religions" $(\mathrm{N}+\mathrm{L}=68 \%)$ considerably in comparison to other personal/social life skills. Also, except for the "Truthfulness in action and speech", "Discipline in life activities", and "Practical belief to religious values and instructions" that their "low" and "nothing" choices are lower than 50 percent, the percent of "low" and "nothing" choices in the other items are more than 50. This shows that they need more attention in the process of preparing Iranian EFL textbooks.

\subsubsection{Leadership Life Skills}

This part of the questionnaire consists of 11 items. Those items represent the operational options of leadership life skills. First, a table on the percent of the answers for each item of this part is presented. Then, the information of the table and the internal consistency of this category are discussed.

Table 5. The percent of the answers for each leadership life skill

\begin{tabular}{|c|c|c|c|c|c|}
\hline $\begin{array}{l}\text { Q: To what extent do your EFL textbook improve the following life skills } \\
\text { in learners? }\end{array}$ & $\begin{array}{l}\text { Very } \\
\text { high }\end{array}$ & High & Middle & Low & Nothing \\
\hline Organizing a group to reach its goal & 3 & 7 & 19 & 35 & 36 \\
\hline Using different leadership styles & 2 & 5 & 7 & 36 & 50 \\
\hline Getting others to share in leadership & 3 & 5 & 28 & 34 & 30 \\
\hline Developing short-term and long-term goals & 4 & 6 & 22 & 40 & 28 \\
\hline Working cooperatively with others & 5 & 11 & 32 & 31 & 21 \\
\hline $\begin{array}{l}\text { Demonstrating responsibility for personal actions and contributions to } \\
\text { group activities }\end{array}$ & 6 & 11 & 24 & 30 & 29 \\
\hline Building of self-confidence and self-esteem (Having firm determination) & 5 & 10 & 15 & 38 & 32 \\
\hline Giving and receiving feedback & 5 & 11 & 28 & 30 & 26 \\
\hline Self-evaluation/assessment & 3 & 8 & 15 & 31 & 43 \\
\hline Managing emotions (anger, stress, etc.) & 6 & 7 & 20 & 30 & 37 \\
\hline Courage and bravery in making decisions and doing different works & 6 & 7 & 13 & 36 & 38 \\
\hline
\end{tabular}

According to these answers, the respondents believed that the Iranian EFL textbooks contains and improve the learners' mastery on "Demonstrating responsibility for personal actions and contributions to group activities" $(\mathrm{VH}+\mathrm{H}=17 \%)$ but not considerably and just in comparison to other items. On the other hand, they believed that the authors of these textbooks paid least attention to the life skills "Using different leadership styles" $(\mathrm{N}+\mathrm{L}=86 \%)$, "Self-evaluation/assessment" $(\mathrm{N}+\mathrm{L}=74 \%)$, and "Courage and bravery in making decisions and doing different works" ( $\mathrm{N}+\mathrm{L}=74 \%)$ among the mentioned leadership life skills. Also, the percent of "low" and "nothing" choices in the all items are more than 50. We can understand that Iranian EFL textbooks don't improve leadership life skills considerably.

\subsubsection{Critical Thinking Life Skills}

This part of the questionnaire includes 11 items. They bring up the practical elements for critical thinking life 
skills. First, a table on the percent of the answers for each item of this part is shown. Then, a brief discussion on the revealed information in the table and the internal consistency of this category are proposed.

Table 6. The percent of the answers for each critical thinking life skill

\begin{tabular}{llllll}
\hline $\begin{array}{l}\text { Q: To what extent do your EFL textbook improve the following life } \\
\text { skills in learners? }\end{array}$ & $\begin{array}{l}\text { Very } \\
\text { high }\end{array}$ & High & Middle & Low & Nothing \\
\hline Analyzing attitudes, values, social norms and beliefs & 4 & 10 & 24 & 27 & 35 \\
Identifying relevant information and information sources & 3 & 11 & 23 & 37 & 26 \\
Applying of technology & 5 & 8 & 20 & 39 & 28 \\
Recognizing bias & 6 & 8 & 17 & 29 & 40 \\
Organizing thoughts to reflecting logical thinking & 6 & 8 & 13 & 36 & 37 \\
Having a deep understanding of more than one issue & 5 & 7 & 21 & 33 & 34 \\
Relating solutions to a wide variety of issues & 4 & 5 & 17 & 38 & 36 \\
Finding answers to challenging questions & 5 & 10 & 19 & 39 & 27 \\
Confident in reaching a reasonable conclusion & 5 & 9 & 22 & 39 & 25 \\
Searching for the truth even when it makes uncomfortable & 6 & 13 & 20 & 32 & 29 \\
Thinking of different ways to answer a question & 5 & 10 & 25 & 33 & 27 \\
\hline
\end{tabular}

Based on the respondents' answers, the Iranian EFL textbooks includes and develop the life skill "Searching for the truth even when it makes uncomfortable" $(\mathrm{VH}+\mathrm{H}=19 \%)$ in the learners more considerably than the other items. On the other hand, they believed that these textbooks don't improve the life skills "Organizing thoughts to reflecting logical thinking" $(\mathrm{N}+\mathrm{L}=73 \%)$ and "Relating solutions to a wide variety of issues" $(\mathrm{N}+\mathrm{L}=74 \%)$ considerably in comparison to other critical thinking life skills. It is also worth mentioning that the percent of "low" and "nothing" choices for all items is more than 60 percent. With this in mind, we can say that Iranian EFL textbooks don't foster these life skills significantly.

\subsubsection{Decision Making/Problem Solving Life Skills}

The category of decision making and problem solving life skills consists of 11 items. These items represent the operational elements for decision making and problem solving life skills. The answers of the respondents to the items of this category are demonstrated in a table. After that, the information in the table and the internal consistency of this category are discussed.

Table 7. The percent of the answers for each decision making/problem solving life skill

\begin{tabular}{llllll}
\hline $\begin{array}{l}\text { Q: To what extent do your EFL textbook improve the following life } \\
\text { skills in learners? }\end{array}$ & $\begin{array}{c}\text { Very } \\
\text { high }\end{array}$ & High & Middle & Low & Nothing \\
\hline Setting goals & 4 & 8 & 37 & 32 & 19 \\
Determining alternative solutions to problems & 5 & 7 & 25 & 39 & 24 \\
Listing options before making a decision & 5 & 9 & 15 & 23 & 48 \\
Thinking about what might happen because of my decision & 6 & 9 & 13 & 37 & 35 \\
Evaluating decisions & 4 & 9 & 17 & 38 & 32 \\
Systemic planning using resources to accomplish a purpose & 5 & 11 & 15 & 30 & 39 \\
Time management & 4 & 18 & 37 & 30 & 11 \\
Conflict resolution & 4 & 9 & 21 & 40 & 26 \\
Working out problems that are presented to me & 5 & 9 & 27 & 39 & 20 \\
Listing all points of views when making decisions & 5 & 8 & 19 & 40 & 28 \\
Consultation & 7 & 10 & 34 & 30 & 19 \\
\hline
\end{tabular}


According to these answers, the respondents believed that the Iranian EFL textbooks contains and improve the learners' mastery on "Time management" $(\mathrm{VH}+\mathrm{H}=22 \%)$ more considerably than the other items. On the other hand, they believed that the authors of these textbooks paid least attention to the life skills "Listing options before making a decision" ( $\mathrm{N}+\mathrm{L}=71 \%)$, "Thinking about what might happen because of my decision" $(\mathrm{N}+\mathrm{L}=72 \%)$, and "Evaluating decisions" $(\mathrm{N}+\mathrm{L}=70 \%)$ among the mentioned decision making/problem solving life skills. Also, except for the "Time management" and "Consultation" that their "low" and "nothing" choices are lower than 50 percent, the percent of "low" and "nothing" choices in the other items are more than 50. It shows that they need more attention in the process of preparing Iranian EFL textbooks.

\subsection{Discussion}

An overall look at the participants' opinions tells us that there are items that were selected as "high" and "very high" by more than 20 percent of the respondents, but the number of these items with this characteristic is very low (about 7 out of 58). On the other hand, there are items that were selected as "low" and "nothing" by more than 70 percent of the respondents (about 10 out of 58). Therefore, we can consider them as distinctive items with a clear message, and other items can be consider as items that do not show us a meaningful hint.

The items that were selected as "high" and "very high" by more than 20 percent of the respondents are "Using body language and gestures for conveying meaning and understanding" and "Observance of lexical and grammatical/structural rules in written utterances" from communication/linguistic life skills and items "Respecting the social and cultural laws and values of the society", "Respecting others' values", "Truthfulness in action and speech", "Discipline in life activities", and "Practical belief to religious values and instructions" from social/personal life skills.

Also, the items that were selected as "low" and "nothing" by more than 70 percent of the respondents are items "Organizing a group to reach its goal", "Using different leadership styles", "Building of self-confidence and self-esteem", "Self-evaluation/assessment", and "Courage and bravery in making decisions and doing different works" from leadership life skills, items "Organizing thoughts to reflecting logical thinking" and "Relating solutions to a wide variety of issues" from critical thinking life skills, and items "Listing options before making a decision", "Thinking about what might happen because of my decision", and "Evaluating decisions" from decision making/problem solving life skills. In addition, we can say that there are 35 items that were selected by more that 60 percent of the respondents as "low" and "nothing".

Another overall statistics shows the average percent of the "high" and "very high" and also the average percent of the "low" and "nothing" choices of items. In group one, 16 percent of the respondents chose "high" and "very high" and 57 percent of them chose "low" and "nothing". The same statistics for group two respectively are 20 and 53, for group three are 12 and 67, for group four are 14 and 66, and for group five are 15 and 62 . The description and expansion of these results and information are discussed in chapter five with more details.

As it was mentioned in this study, McKay (2003) believes that in the light of English as an international language, the social and cultural content of EFL textbooks should not be limited to native English-speaking countries and should contain local social and cultural content too. Besides, Isik (2008) claims that dealing with familiar issues, context (basically home culture), increases the personal attachment of both learners and teachers. Therefore, as the results showed, Iranian EFL textbooks tried not to be limited to the culture of native English-speaking countries and included some local cultural contents. Although they were not totally successful, their attempt should be appreciated. It should be also mentioned that the positive points and successful parts are lower than weak and negative points and parts. Having this in mind, the Iranian material developers and syllabus designers should work and try more to match the socio-cultural constructs of Iranian EFL textbooks with the Islamic-Iranian society of Iran.

\section{Conclusion}

According to the results gathered in the process of this study, it can be concluded that communication/linguistic life skills and personal/social life skills can be improved more by Iranian EFL textbooks. For these life skills, the amount of positive answers is more and negative answers lower than other categories. It should be considered that there is a long way to the ideal part and these interpretations are stated in comparison with other life skills in the questionnaire.

In contrast, leadership life skills, critical thinking life skills, and decision making/problem solving life skills cannot be improved by Iranian EFL textbooks significantly. In other words, these life skills have the most negative and the least positive answers among the filled questionnaires.

It should be mentioned that creating great textbooks, alone, will not necessarily improve students' life skills. 
There is the huge topic of pedagogy and teacher training that needs to also be addressed.

\subsection{Pedagogical Implications}

This research has some pedagogical implications. First and for most, the educational policy makers of ELT in the ministry of education of Iran should be aware of this sensitive point in relation with Iranian EFL textbooks. As it is mentioned in the Fundamental Transformation Document of the ministry of education of Iran, the socio-cultural constructs of Iranian textbooks should include Islamic-Iranian contents and EFL textbooks are not exceptions. Also, we should use English courses as means of preparing students for future life.

In addition to educational policy makers, the syllabus designers and material developers should consider the important points mentioned above. Also, the teachers can be good lifters of these shortages. They can add appropriate cultural supplements for the contents of Iranian EFL textbooks.

\subsection{Suggestions for Further Research}

There are many areas related to the topic of this thesis that can be worked on. Different suggestions that are directly and indirectly related to the topic and content of this research are mentioned below.

First of all, Iranian EFL textbooks can be analyzed from different point of views. In other words, other constructs of these textbooks can be analyzed. The researcher in this project worked on the socio-cultural constructs of the Iranian EFL textbooks.

Secondly, a comparison between Iranian EFL textbooks and other EFL textbooks worldwide can be done with regard to socio-cultural constructs or other constructs of those textbooks.

Thirdly, a similar research can be done on the newly published Iranian EFL textbook of seventh grade (grade one of junior high school) of Iranian public schools. The results of such research can be a good comparison between the former textbook and the new one.

\section{Acknowledgments}

The researchers would like to acknowledge dear EFL teachers of the ministry of education and their students who participated in this research and carefully filled the questionnaire of the study.

\section{References}

Alemi, M., \& Rezanezhad, A. (2013). Academic Word List: Coverage Range in Local/Global Textbooks and Exploring Effective Ways of Teaching and Testing of AWL. IARTEM e-Journal, 5(2), 23-41.

Aliakbari, M. (2002). Culture in ELT programs: An evaluation of the issue of culture in the Iranian ELT program in the high school level (Unpublished master's thesis, Esfahan University, Esfahan).

Alptekin, C. (1993). Target-language culture in EFL materials. ELT Journal, 47(2), 136-143.

Alptekin, C., \& Alptekin, M. (1984). The question of culture: EFL teaching in non-English speaking countries. ELT Journal, 38(1), 14-20.

Amalsaleh, E. (2004). The representation of social actors in the EFL textbooks in Iran (Unpublished doctoral dissertation, Shiraz University, Shiraz).

Amerian, M. (1987). A comparative study of the graded English and the right path to English series with regard to content and methodology (Unpublished master's thesis, Shiraz University, Shiraz).

Ansary, H., \& Babaii, E. (2002). Universal characteristics of EFL/ESL textbook: A step towards systematic textbook evaluation. The Internet TESL Journal, 2, 1-8.

Ashraf, H. (2011). Research Articles' Critical Reading: Developing an Effective Approach in an EFL Context. Iranian EFL Journal, 7(1), 67-90.

Ashraf, H., \& Khosravani, M. (2012). Semantic Clustering of L2 Vocabularies: Effective in Critical Thinking and Vocabulary Learning (pp. 670-679). Proceeding of Lorestan TELL conference.

Azizifar, A., Koosha, M., \& Lotfi, A. R. (2009). An analytical evaluation of Iranian high school ELT textbooks from 1970 to the present. Procedia Social and Behavioral Sciences, 3, 36-44.

Baghaei, P., \& Motallebzadeh, K. (2012). An Appraisal of "Establishing a Life-Language Model of Proficiency: A New Challenge for Language Testers" by Pishghadam and Zabihi (2012). Iranian Journal of Language Testing, 2(2), 116-119.

Dolati, I., \& Mikaili, P. (2011). Opinions related to the main reasons on Iranian Students' difficulties in Spoken English proficiency. Australian Journal of Basic and Applied Sciences, 5(11), 1142-1148. 
Garinger, D. (2001). Textbook evaluation. TEFL Web Journal, 10(3), 1-18.

Guest, M. (2002). A critical check book for culture teaching and learning. ELT Journal, 56(2), 154-161.

Hutchinson, T., \& Torres, E. (1994). The textbook as agent of change. ELT Journal, 48(4), 315-328.

Isik, A. (2008). Linguistic imperialism and foreign language teaching. The Journal of Asia TEFL, 5(1), 123-144.

Kheibari, S. (1999). Text analysis and evaluation of TEPSOL coursebooks (Unpublished master's thesis, Shiraz University, Shiraz).

Linton, R. (1945). The Cultural background of personality. New York.

McGrath, I. (2002). Materials Evaluation and Design for Language Teaching. Edinburgh: Edinburgh University Press.

Naji, M., \& Pishghadam, R. (2013). Analysis of English language textbooks in the light of English as an International Language (EIL): A comparative study. International Journal of Research Studies in Language Learning, 2(2), 83-96.

Pishghadam, R., \& Zabihi, R. (2013). Introducing and Exemplifying English for Life Purposes (ELP) as a new Concept in English Language Teaching. Humanizing Language Teaching, 15(3), 1-19.

Pishghadam, R., \& Zabihi, R. (2012a). Life syllabus: A new research agenda in English language teaching. TESOL Arabia Perspectives, 19(1), 23-27.

Pishghadam, R., \& Zabihi, R. (2012b). Establishing a life-language model of proficiency: A new challenge for language testers. Iranian Journal of Language Testing, 2(2), 93-108.

Pishghadam, R. (2011). Introducing Applied ELT as a new approach in second/foreign language studies. Iranian EFL Journal, 7(2), 8-14.

Razmjoo, S. A. (2007). High Schools or Private Institutes Textbooks? Which Fulfill Communicative Language Teaching Principles in the Iranian Context? Asian EFL Journal, 9(4), 126-140.

Riazi, A. M. (2003). What textbook evaluation schemes tell us? A study of the textbook evaluation schemes of three decades. In W. A. Renanda (Ed.), Methodology and materials design in language teaching (pp. 52-68). Singapore: SEAMEO Regional Center.

Nikou, F. R., \& Soleimani, F. (2012). The manifestation of culture in Iranian and Turkish high school English textbooks. Academic Research International, 2(3), 646-656.

Shahedi, S. (2001). Constructing an analytical framework for the analysis of Persian language texts for foreign learners (Unpublished master's thesis, Shiraz University, Shiraz).

Sheldon, L. E. (1988). Evaluating ELT Textbooks and Materials. ELT Journal, 42(4), 237-246.

Talebinezhad, M. R., \& Aliakbari, M. (2001). Basic assumption in teaching English as an international language. The Internet TESL Journal, 6(7), 23-42.

Thompson, J. (1990). Ideology and modern culture. Stanford, CA: Stanford University Press.

Yarmohammadi, L. (2002). The evaluation of pre-university textbooks. The Newsletter of the Iranian Academy of Science, $18,70-87$.

\section{Apendix}

Life Skills Questionnaire

In the Name of Almighty

Dear teacher/student:

This is a questionnaire for assessing the amount of life skills expression in socio-cultural constructs of Iranian EFL public textbooks.

Many thanks for your cooperation.

Participants' specifications:

Name: (optional) Gender: male $\square$ female

Age: 20-30

$30-40$

$40-50$

Over 50

Degree: $\mathrm{AD} \square$ BA $\square$ MA $\square$ PhD $\square$ Province:

Considered textbook: Junior high school: $1 \square \quad 2 \square \quad 3 \square$ Senior high school: $1 \square 2 \square 3 \square$ 
To what extent the considered textbook improve the following life skills Very in learners?

Communication/Linguistic Life Skills

1 Effective verbal and non-verbal communication with others that help the students to establish relationships

2 Expressing of feelings, ideas and opinions clearly

3 Giving and receiving feedback

4 Understanding other people's viewpoints

5 Organizing thoughts to reflect logical thinking and speaking

6 Influencing \& persuading others

7 Expressing respect for others' contributions

8 Learning how to criticize and reply/react criticisms

9 Respecting and tolerating opposite and various comments (Being patient in relation with others)

10 Active listening (real situations like in classes, airports, shops, watching films, listening to music, etc.)

11 Fluency and accuracy in speaking (real situations like in airports, shops, etc.)

12 Correct reading and study skills (even newspapers, stories, novels, etc.)

13 Using body language and gestures for conveying meaning and understanding

14 Observance of lexical and grammatical/structural rules in written utterances

Personal/Social Life Skills

1 Developing of personal identity

2 Respecting the social and cultural laws and values of the society

3 Respecting others' values

4 Acquiring of social responsibilities

5 Truthfulness in action and speech

6 Respecting older generations (including parents, adults, and teachers)

7 Respecting other religions

8 Discipline in life activities

9 Respecting and observance of people's right (e.g. in public places, traffic rules, sin against mankind, etc.)

10 Team and group work

Practical belief to religious values and instructions (e.g. praying,

11 fasting, veil, honesty, depositary, avoiding backbiting, finding good friends, etc.)

\begin{tabular}{ll}
\hline Leadership Life Skills \\
\hline 1 & Organizing a group to reach its goal \\
2 & Using different leadership styles \\
3 & Getting others to share in leadership \\
4 & Developing short-term and long-term goals \\
5 & Working cooperatively with others \\
6 & $\begin{array}{l}\text { Demonstrating responsibility for personal actions and contributions } \\
\text { to group activities }\end{array}$
\end{tabular}


7 Building of self-confidence and self-esteem (Having firm

determination)

8 Giving and receiving feedback

9 Self-evaluation/assessment

10 Managing emotions (anger, stress, etc.)

11 Courage and bravery in making decisions and doing different works

Critical Thinking Life Skills

1 Analyzing attitudes, values, social norms and beliefs

2 Identifying relevant information and information sources

3 Applying of technology

4 Recognizing bias

5 Organizing thoughts to reflecting logical thinking

6 Having a deep understanding of more than one issue

7 Relating solutions to a wide variety of issues

8 Finding answers to challenging questions

9 Confident in reaching a reasonable conclusion

10 Searching for the truth even when it makes uncomfortable

11 Thinking of different ways to answer a question

Decision Making/Problem Solving Life Skills

$1 \quad$ Setting goals

2 Determining alternative solutions to problems

3 Listing options before making a decision

4 Thinking about what might happen because of my decision

5 Evaluating decisions

6 Systemic planning using resources to accomplish a purpose

7 Time management

8 Conflict resolution

9 Working out problems that are presented to me

10 Listing all points of views when making decisions

11 Consultation

\section{Copyrights}

Copyright for this article is retained by the author(s), with first publication rights granted to the journal.

This is an open-access article distributed under the terms and conditions of the Creative Commons Attribution license (http://creativecommons.org/licenses/by/3.0/). 